\title{
Exploring Relationship Among Customer Dissatisfaction, Complaints, And Loyalty In The Virtualized Environment: Roles Of Advanced Services
}

\author{
Yoon C. Cho, KDI School of Public Policy and Management, Korea
}

\begin{abstract}
Various studies support how satisfied customers become loyal customers by investigating attitudes and behavior, while fewer studies have examined links among dissatisfaction, complaints, and loyalty, particularly in the virtualized environment. By applying justice dimension, the purpose of this study is to explore i) how different types of justice affect customer dissatisfaction; ii) how the level of customer dissatisfaction affects willingness to complain/complaining behavior; iii) how willingness to complain/complaining behavior affects repeat purchase behavior based on how complaints are resolved by a company; and iv) how repeat purchase behavior affects loyalty. Proposed relationships are investigated with effects of advanced services (i.e., 2Is, Interactivity and Individualization) and product category that are applied in the virtualized environment. By applying various statistical analyses, this study provides managerial and theoretical implications and offers suggestions to e-businesses.
\end{abstract}

Keywords: Virtualization; Justice; Dissatisfaction; Complaining Behavior; Loyalty; Roles of Advanced Services (Interactivity and Individualization); Product Category

\section{INTRODUCTION}

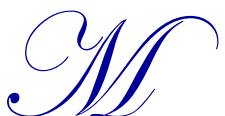

ost e-commerce innovations gradually absorb behavior as customers prove their worth beyond the initial trial phrase. The Web-based, so called virtualized environment switches and affects customers' perception and attitudes about product attributes, prices, and intangible services differently from the traditional offline environment. Virtualization defines with concepts of "presence" and "telepresence," which refer to the sense of being in the environment, generated by mediated means (Steuer 1992). Steuer (1992) also states that virtual reality, typically portrayed as a medium with the aid of technology-based view, is an electronic simulation of environments experienced via head-mounted eye goggles and wired clothing, enabling the end user to interact in realistic three-dimensional situations (Coates 1992). Previous studies address resolution to maximize customer satisfaction and minimize dissatisfaction and complaints over the environment due to the lack of a physical environment (Steuer 1992), which is also known as telepresence or computer-mediated shopping environments (Hoffman and Novak 1996). Jung, Cho, and Lee (2011) state that the nature of telepresence created by this virtualization process, enabling individuals, organizations, and automated systems to coordinate all aspects of the consumer buying process, which affects customers' acceptance of and willingness to purchase products/services.

Various studies discuss the differential effects of customer attitudes and behavior in the virtualized environment compared to the physical environment. Noticeable changes due to the virtualization, such as lack of delivering all senses, raise issues of perception of products and services in cyberspace (Peppard and Rylander 2005; Rhee, Riggins, and Kim 2009). Figueiredo (2000) highlighted this issue by providing product categories, which were based on how quality is not easily determined on the Web. A study by Cho (2011) addressed importance of advanced services, such as customization, in the case of purchase decision via virtualized environment particularly when customers consider products that contains sensory attributes. Studies examined the issue to the consumer adoption of online buying behavior of products that have sensory attributes (Hansen 2005; Verhoef and Langerak 
2001), buying intention (Shim, Lotz, and Warrington 2001), effects of dissatisfaction and regret (Cho 2011), and loyalty (Thorbjornsen and Supphelen 2004). Prior studies also applied various perspectives to address different effects in the virtualized environment by exploring situational/environmental factors with retail format preferences (Gehrt, Ingram, and Howe 1991; Gehrt and Yan 2004; Palmer 1997), inherent structural and functional weakness of Internet retailing (Grewal, Iyer, and Levy 2004), virtual store acceptance (Chen and Tan 2004), factors affecting e-CRM (Lages, Lages, and Rita 2004; Cho, Im, Hiltz 2003), effects of webpage (Stevenson, Gordon, Anand 2000), perception of price, (Pitt, Watson, and Ewing 2001), effects of agents on prices (Jung, Cho, and Lee 2011; Iyer and Pazgal 2003), price dispersion (Pan, Ratchford, and Shankar 2004), and search cost (Bakos 1997).

A previous study by Cho and Agrusa (2007) applied approaches to customer satisfaction measurement that accounted for the realities in the virtualized environment. Various researchers determine the issue of customer satisfaction and customer loyalty to be at the center of the successful brick-and-mortar physical and click-and-mortar online business exchanges. However, researchers examine to a lesser extent the issues beyond concepts of customer dis/satisfaction and the underlying theories and models that attempt to explain why people may not be satisfied or loyal. In particular, researchers study relationships of online customer attitudes, satisfaction (Cho 2010) /dissatisfaction (Cho 2011), propensity to complain (Bearden, Crockett, and Graham 1979; Cho, Im, Hiltz, and Fjermestad 2001) /complaining behavior (Blodgett, Hill, and Tax 1997; Tax, Brown and Chandrashekaran 1998), and loyalty (Reichheld and Schefter 2000) in the virtualized environment much less. Oliver (1997) stated that dissatisfaction is another side of satisfaction regarding ways to remedy feelings of discomfort and related actions, such as complaining behavior (Cho 2011). A study by Ping (1993) investigates the associations among satisfaction/dissatisfaction, exiting, voice (constructive attempts to change conditions), loyalty, and neglect in a channel relationship. Based on the considerations above, this study explores how e-commerce companies deal with customer dissatisfaction and complaints, which may affect loyalty in ways that might lead to managerial changes improving long-term customer relationship management. Further, this study examines relationships of negative sides of satisfaction to the loyalty by exploring roles of advanced services and product category.

Studies (Blodgett, Hill, and Tax 1997; Tax Brown and Chandrashekaran 1998) classify justice dimensions by exploring how perceived justice dimensions affect dissatisfaction as well as better service recovery and by considering the different types of dissatisfaction (Gustafsson 2009). This study also investigates effects of perceived justice that is often addressed with the issue, such as service recovery (Gustafsson, 2009; Río-Lanza, Vazquez-Casielles, and Diaz-Martin forthcoming), along with product categories that are classified based on the characteristics of telepresence. Prior studies (Cho 2011, Figueiredo 2000) address how customers perceive and purchase a product in the virtualized environment differently due to various attributes of products delivered without presence of the product. Studies (e.g., Mohammed, Fisher, Jaworski, and Cahill 2002) and practitioners address the roles of the advanced services, 2Is (i.e., Interactivity and Individualization) and determine prerequisites, drivers, and solutions in a rich communication environment to minimize such limitation as the lack of the product being present. In particular, prior studies highlight importance of perceived Web site interactivity (Song and Zinkhan 2008) as a key aspect of telepresence (Steuer 1992). Song and Zinkhan (2008) summarized examples of site (system) features such as speed (e.g., response time), communication dimensions (e.g., feedback mechanisms, order status tracking service), and sensory complexity. Prior studies (e.g., Moreau, Bonney, and Herd 2011, Thongpapanl and Ashraf 2011) also mention that individualization (i.e., customization and personalization) also plays important role to reduce anxiety and improve customer satisfaction.

Based on those considerations, the purpose of this study is to investigate the relationships among types of justice, dissatisfaction, intention to complain, complaining behavior, and loyalty. In particular, this study explores i) the relationship of justice to customer dissatisfaction; ii) the relationship of dissatisfaction to the willingness to complain and complaining behavior; iii) the relationship of willingness to complain and complaining behavior to the repeat purchase intention; and iv) the relationship of repeat purchase intention to the loyalty by classifying two segments based on experiences of purchasing non-sensory products and sensory products. This study investigated how the advanced services, 2Is, which are considered solutions to the Internet, play an important role in examining the proposed relationships of variables including dissatisfaction, willingness to complain, complaining behavior, repeat purchase intention, and loyalty by resolving the level of complaints. This study also measured proposed impacts with classified product categories by considering characteristics of virtualized environment, how quality of senses is determined differently. 


\section{HYPOTHESES DEVELOPMENT}

Prior researchers have widely investigated topics on customer satisfaction with online experiences while there has been limited research on the issues of dissatisfaction and complaining behavior. Studies on the negative side of satisfaction address issues by developing the confirmation/disconfirmation paradigm (Oliver 1980), defensive marketing (Chu, Gerstner, and Hess 1998), as well as Hirschman's (1970) theory of exit, voice (constructive attempts to change conditions), and loyalty that provides the basic framework for the study of customer complaining behavior (CCB). Early work in consumer satisfaction/dissatisfaction applies predictive expectations as a standard, disconfirmation of expectations, or expectancy disconfirmation in order to explain the level of discrepancy of probability of desirable events that occur (Oliver 1997). A previous study by Oliver (1997) also discusses the level of disconfirmation with the focus on uncertainty, such as desirability of alternatives, performance, and adequacy of chosen alternatives, which are also considered as a basis for understanding why customers are dissatisfied and regretful. Associated dissonance explained by the dissonance theory (Festinger 1957), addresses how consonant and dissonant relations, which may occur during the purchase decision phases, would apply to a consumer's decision (Oliver 1997). A study by Huefner and Hunt (2000) explains how disconfirmation and dissonance affect dissatisfaction and propensity to complain/complaining behavior, such as retaliation and loyalty. Huefner and Hunt (2000) also expand upon Hirschman's (1970) theory of exit, voice, and loyalty by including retaliation. The exit, voice, and loyalty model (Hirschman 1970) also provides implications of how voice, along with dissatisfaction affects loyalty based upon how it is treated and resolved. Theories such as contrast theory, which explains the relationship between expectation and outcome, also support issues on dissatisfaction (Engel and Blackwell 1982; Howard and Sheth 1969; Cardozo 1965). Furthermore, other studies (Berry and Parasuraman 1991; Dwyer et al. 1987; Gustafsson 2009) apply theoretical background on customer dissatisfaction to complaint handling, which is a critical moment of truth in maintaining and developing customer relationships.

Prior studies classify customer dissatisfaction based upon customers' perceptions of justice (Blodgett, Granbois, and Walters 1993; Blodgett, Hill, and Tax 1997). Tax, Brown, and Chandrashekaran (1998) study highlight the effects of justice and satisfaction/dissatisfaction on complaint handing and provide implications for relationship marketing. A study by Blodgett, Hill, and Tax (1997) considers perceived justice, classified into three categories, namely distributive justice (e.g., equity, equality, and need), procedural justice (e.g., process control, decision control, accessibility, timing/speed, and flexibility), and interactional justice (e.g., explanation/causal account, honesty, politeness, effort, and empathy) as a valuable framework for explaining customers' reactions to complaint episodes. This framework also provides direction to service marketing by addressing the importance of process and interpersonal communication during the service encounter (Blodgett, Hill, and Tax 1997; Bitner, Booms, and Tetreault, 1990; Solomon, Surprenant, Czepiel, and Gutman, 1985).

This study posits that customers' perceptions of justice differ in the virtualized environment based on the advanced services and product category that are offered. As shown in the proposed model (Figure 1), this study measures how the types of justice experienced during online purchase transactions affect dissatisfaction based on the product category, sensory vs. non-sensory. This study posits how customers perceive product attributes and how senses delivered in the online environment affect the justice factors, such as perceived equality, effort, and timing. This study also examines the relationships among dissatisfaction, willingness to complain, complaining behavior, repeat purchase intention, and loyalty in the online environment. The study applies effects of the 2Is (Interactivity and Individualization) proposed as significant factors in creating customer relationships on the Internet (Mohammed, Fisher, Jaworski, and Cahill 2002) particularly in the process of dissatisfaction, willingness to complain/complaints, and to the loyalty. Both theoretical (Cho 2011; Steuer 1992; Song and Zinkhan 2008) and practical examples (e.g., Amazon.com's recommender system, collaborative filtering system, or virtual agents) have addressed the roles of 2Is. Interactivity refers to the extent to which a two-way flow of communication occurs between the firm and the customer; and individualization reflect the degree to which the firm customer interactions are tailored or customized to the individual user. With the consideration of future acceptance of virtual shopping, this study investigates how advanced services generated with 2Is take a role to resolve the level of dissatisfaction and complaints and affect the repeat purchase intention. 


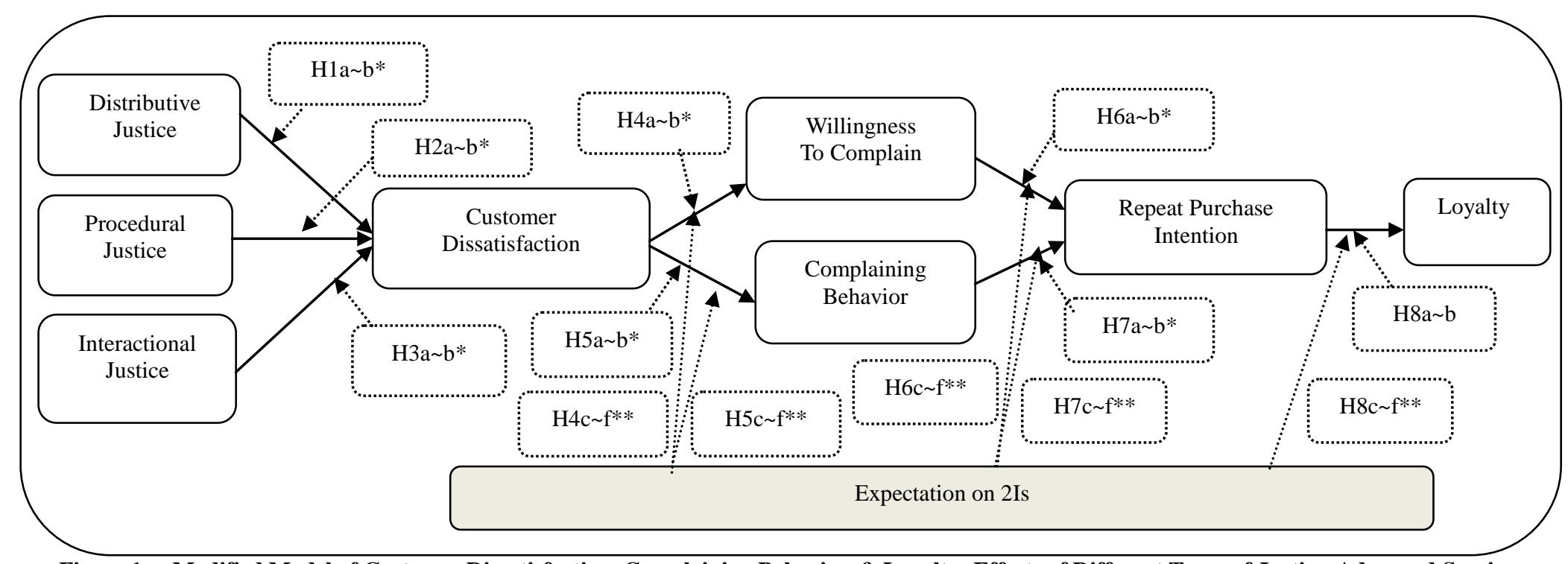

Figure 1: Modified Model of Customer Dissatisfaction, Complaining Behavior, \& Loyalty: Effects of Different Types of Justice, Advanced Services, $\&$ Product Category (Modified from Blodgett, Hill, and Tax 1997 and Oliver 1980)

*Hypotheses "a"s are applied for the case of non-sensory while hypotheses "b"s are applied for the case of sensory products.

**Hypotheses "c"s are applied for the effects of interactivity \& non-sensory products; "d"s are applied for the effects of interactivity \& sensory products; "e"s are applied for the effects of individualization \& non-sensory products; and " $\mathrm{f}$ "s are applied for the effects of individualization \& sensory products. 
This study applies the impacts of advanced service with product category. Rhee, Riggins, and Kim (2009) mention product type as an important contingent variable in net-enabled commerce systems and for e-business success, particularly with user adoption, perceived attributes of a technology, and online purchasing experience. Product classification in the virtualized environment also includes sensory vs. non-sensory, as the customer adopts attributes differently due to the inherent characteristics of the Internet (Cho, Im, Fjermestad, and Hiltz 2003), without the sense of being present (Steuer 1992). The role of sensation, the immediate response of sensory receptors and significant stimuli, affects consumer choice behaviors in the online environment through the perceptual process (Solomon, 2009; Jung, Cho, and Lee 2011). Prior studies examine customers' perception of products in the virtual world by addressing how quality is easily determined (Figueiredo 2000), different perceptions of product attributes due to the innovation characteristics (Hansen 2005), and product attributes with expectation and regret (Cho 2011). Studies (e.g., Jung, Cho, and Lee 2011) address issues on product categories in the virtualized environment with respect to how the level of senses is delivered. This study examines the manners by which customers perceive justice during the transaction, along with product categories.

\subsection{Perceived Justice}

Oliver (1980) states that equity and justice are classical experimental paradigms, by considering manipulated outcome/input ratios. This posits a direct path from outcome/input combinations to satisfaction along with fairness in purchasing and consumption (Oliver 1980; Oliver 1997). Theoretically, equity principles predict that the focal consumer will compare her/his outputs and outcomes to those expected (or predicted) by another individual (Oliver 1997), as it is also explained by the rule of justice by Homans (1961). Oliver (1980) states that equity exists on a continuum bounded by negative and positive inequity, where outcomes are less than or greater than deserved. Prior studies examine the concept of perceived justice as a valuable framework that supports different types of justice (Blodgett, Hill, and Tax 1997), the relationship among fairness or perceived justice, emotions, and satisfaction over the service recovery process (Río-Lanza, Vazquez-Casielles, and Diaz-Martin forthcoming), the effects of perceived justice on complainants' negative word-of-mouth behavior and repatronage intentions (Blodgett, Granbois, and Walters 1993), the impact on customer satisfaction and intention to complain in a service recovery (Hocutt, Chakraborty, and Mowen 1997), and cross-cultural comparison (Hui and Au 2001). A study by Cho, Im, and Hiltz (2003) applies the concept of perceived justice to investigate causes of complaints and service failure in the virtualized environment. Perceived justice is actually a broad, multifaceted construct, which encompasses three dimensions: distributive justice, interactional justice, and procedural justice (Bies and Shapiro, 1987; Clemmer and Schneider, 1996).

\subsubsection{Distributive Justice}

Oliver (1997) also indicates that classifying the phenomena of differing roles that forms the purchase and consumption aspects of inequity explains justice. Developed from social exchange theory, marketing exchanges are considered benefits and costs (Deutsch 1985) involving consumers, distributive justice, or what has come to be known as expectations states theory, which explains how each party has expectations of the role of the other (Berger, Conner, and Fisek 1974; Oliver 1997). A previous study (Tax, Brown, and Chandrashekaran 1998) treats distributive justice as the extent to which customers feel they have been treated fairly with respect to the final recovery outcome. Maxham and Netemeyer (2002) consider distributive justice as representative outcomes from refunds, discounts, and other forms of atonement offered to customers following a failure. The concept of distributive justice, as a valuable framework, explains customers' reactions to complaint episodes (Blodgett, Hill, and Tax 1997) and the importance of process and interpersonal communication during the service encounter (Bitner, Booms, and Tetreault, 1990). According to Blodgett, Hill, and Tax (1997), distributive justice encompasses the perceived fairness of the policies and procedures used by the seller in a consumer complaint context. Various studies describe the causes of satisfaction/dissatisfaction in the online environment. However, far less research investigates how the concepts of justice classify based on those proposed causes. This study hypothesizes that the effects of perceived distributive justice from online shopping significantly affect dissatisfaction in the cases of both sensory and non-sensory products. This study hypothesizes "a"s for the case of non-sensory products and " $b$ "s for the case of sensory products.

H1a b: Higher levels of perceived distributive justice from online shopping affect higher levels of dissatisfaction in the purchase of both non-sensory and sensory products. 


\subsubsection{Procedural Justice}

Procedural fairness explores the manner in which the outcomes were delivered (Oliver 1997). Oliver (1997) classifies three elements that play a significant role: i) the ability to participate in the distribution decision including the chance to provide information; ii) the belief that the information is used in the decision; and iii) the feeling that one's participation influences the outcome. Prior studies (Folger 1987; Greenberg 1990) state that procedural justice is meaningful because it aims to resolve conflicts in ways that encourage the continuation of a productive relationship between the disputants, even when outcomes are unsatisfactory to one or both parties. Blodgett, Hill, and Tax (1997) mention that procedural justice encompasses the perceived fairness of the policies and procedures used by the seller in processing a complaint (see also Blodgett, Granbois, and Walters 1993). According to the review of justice elements and associated research by Tax, Brown, and Chandrashekaran (1998), factors that affect procedural justice include process control (Goodwin and Ross 1992, Lind \& Tyler 1988), decision control in which a person is free to accept an outcome (Brett 1986), accessibility (Bitner, Booms, and Tetreault 1990), timing/speed (Fisk and Coney 1982; Taylor 1994), and flexibility (Bitner, Booms, and Tetreault 1990). This study examined how customers' perceive procedural fairness online increases due to factors such as adaptability of procedures to reflect individual circumstances (Bitner, Booms, and Tetreault 1990; Cho, Im, and Hiltz 2003) and perceived amount of time taken to complete a procedure (Fisk and Coney 1982; Taylor 1994). This study hypothesizes that the effects of perceived procedural justice from online shopping significantly affect dissatisfaction in the cases of both non-sensory and sensory products.

H2a b: Higher levels of perceived procedural justice from online shopping affect higher levels of dissatisfaction in the purchase of both non-sensory and sensory products.

\subsubsection{Interactional Justice}

Previous studies (Blodgett, Granbois, and Walters 1993; Blodgett, Hill, and Tax 1997) address the effects of interactional justice which have focused on the manner in which the complainant was addressed. A prior study (Maxham and Netemeyer 2002) addresses interactional justice as the extent to which customers feel they have received fair treatment regarding their personal interaction with service agents throughout the recovery process. Oliver (1997) states that equity standards for interactional justice include common dignity, such as respect and politeness, which is owed to all members of society and differs from procedural fairness. Interactional justice pertains to the person-to-person dealings that provide the process of justice (Oliver 1997), which are crucial elements of complaint handling (Maxham and Netemeyer 2002) and relationship marketing (Tax, Brown, and Chandrashekaran 1998). A study by Tax, Brown, and Chandrashekaran (1998) reviewed important factors for interactional justice, such as providing a reason for a failure (Bies and Shapiro 1987, Bitner, Booms, and Tetreault 1990), perceived veracity of information provided (Goodwin and Ross 1989), well-mannered and courteous behavior (Blodgett, Hill, and Tax 1997; Clemmer and Schneider 1996; Goodwin and Ross 1989), effort (Folkes 1984), and empathy (Parasuraman, Zeithaml, and Berry 1988). A study by Cho, Im, and Hiltz (2003) applies how those dimensions affect a propensity to complain and for service recovery in the virtualized environment. This study posits that major dissatisfaction and complaints in an online setting, comprised of a lack of physical interaction between customers and business, may be resolved well by adopting advanced strategies. This study hypothesizes that the effects of perceived interactional justice from online shopping significantly affect dissatisfaction in the cases of both non-sensory and sensory products.

H3a b: Higher levels of perceived interactional justice from online shopping affect higher levels of dissatisfaction in the purchase of both non-sensory and sensory products.

\subsection{Dissatisfaction and Complaining Behavior}

This study examines a model of encompassing interrelationships among expectations, disconfirmation, satisfaction, and the traditional criteria of attitudes and intentions (Oliver 1980; Bearden and Teel 1983) in order to explain dissatisfaction, the negative state of satisfaction. Cohen and Goldberg (1970) also explain dissatisfaction by other models, such as the cognitive dissonance model in post-decision product evaluation as the process of perceived feeling. Previous studies extend the research on dissatisfaction by incorporating consumer complaining behavior 
into a theoretical model of consumer satisfaction (Bearden and Teel 1983). Some studies (Bearden and Teel 1983; Day and Landon 1977) describe consumer complaint behavior as the process by which the dissatisfaction effects action (private or public) or no action based upon the propensity to complain. Hirschman (1970) classifies reactions of dissatisfied customers as exit (stop consuming the product), voice (tell management what is wrong and what is expected), or remain loyal (continue to purchase the product). By considering such an encompassing relationship between dissatisfaction and complaining behavior, previous studies posit the use of defensive marketing designed to propose a system to handle complaints by dissatisfied customers (Chu, Gerstner, and Hess 1998) and to manage the long-term relationships by examining structural constraints (Ping 1993). While various studies examine the relationship between dissatisfaction and complaining behavior, few studies examine it in the virtualized shopping environment. By classifying groups of customers who are willing to complain and actually do complain, this study hypothesizes how the dissatisfaction from online shopping affects the willingness to complain and actual complaining behavior. This study also hypothesizes the effects based on the products, sensory or non-sensory. Further, this study also hypothesizes the effects based on the role of advanced services (see 2.4).

H4a b: Higher levels of dissatisfaction from online shopping lead to higher willingness to complain when purchasing both non-sensory and sensory products.

H5a b: Higher levels of dissatisfaction from online shopping lead to the higher tendency of actual complaining behavior when purchasing both non-sensory and sensory products.

\subsection{Complaining Behavior, Repeat Purchase Behavior, \& Loyalty}

Some studies (Tax, Brown, and Chandrashekaran 1998; Berry and Parasuraman 1991) address complaint handling as a critical factor in maintaining and developing relationships on satisfaction and customer loyalty. Loyalty is regarded as an ultimate stage in the model of customer satisfaction, after the links among constructs, such as expectation, dis/confirmation, dis/satisfaction, and complaining behavior, which also becomes a significant variable for relationship marketing. However, studies that examine such links between how customer complaining behavior affects loyalty, to the degree of how complaints are resolved are much less examined. In particular, researchers have not investigated propositions of the relationship between complaining behavior and loyalty in the virtualized environment. By considering online specific characteristics, such as stickiness (Reichheld 1993), and various application of the system, such as real chat system and customized resolution, this study posits that customers' willingness to complain and complaining behavior affect repurchasing a product or service based upon how complaints are resolved. This study also posits that the degree of effects will differ from non-sensory and sensory products as we expect the difference between expectation and received products' outcome due to the virtualized process. Further, this study also hypothesizes the effects based on the role of advanced services (see 2.4).

H6a b: Higher levels of willingness to complain affect higher levels of repurchase intention for cases of purchasing both non-sensory and sensory products.

H7a b: Higher levels of complaining behavior affect higher levels of repurchase purchase intention when the complaints are resolved for cases of purchasing both non-sensory and sensory products.

H8a b: Higher levels of repurchase intention affect increased loyalty for cases of purchasing both non-sensory and sensory products.

\subsection{Roles of Advanced Services}

This study also hypothesizes that the effects differ based on the roles of advanced services, 2Is, individualization and interactivity, referred to as technology mediated services (Schumann, Keller, Wangenheim, and Holzmuller 2007). A study by Mohammed, Fisher, Jaworski, and Cahill (2002) states that the roles of 2Is, addressed as factors unique to the Internet, offer possible solutions to minimize the dissatisfaction and complaints in the virtualized environment (Cho 2011). A study by Chu, Gerstner, and Hess (1998) also addresses the need to develop different policies and systems such as 2Is to handle complaints by dissatisfied customers to keep existing customers satisfied. Theories such as telepresence theory (Steuer 1992) and interactivity theory (Rafaeli 1998) explain the roles of 2Is in the virtualized environment, which provide a conceptual basis for identifying key features of interactivity perceptions (Song and Zinkhan 2008). Song and Zinkhan (2008) also stated that interactivity theory addresses the quality of the communication (i.e., how reciprocal a particular exchange is) as the most important determinant of interactivity. 
Interactivity has been often used as a synonym for new media (McMillan and Hwang 2002) in the early stage of the Internet. Interactivity is defined as Web users' internally based efficacy, or in other words, Web users' perceived control over where they are and where they are going (Wu 1999; Song and Zinkhan 2008). Wendy (2003) defined that interactivity is the state of process of communicating, exchanging, obtaining and/or modifying current (e.g., ideas, entertainment, product information) and/or its form with or through a medium (e.g., computer, modem, etc) which responds to both the communicator's and the audience's communication needs by including hyperlinks, reciprocal communications, etc. (Wendy 2003). The role of interactivity has been addressed as a solution to enhance better transaction in the virtualized environment to overcome the limitation of physical presence. Technological tools are developed for interaction via computer, such as chat-room, e-mail system, and bulletin boards that might replace "interpersonal interaction" (Massey ad Levy 1999). Previous studies state that virtual employees, also called intelligent virtual agents (Kohler, Rohm, Ruyter, and Wetzels 2011) as one of the most promising technologies (Clarkson 2010) that replace human service and a social cue influences customer satisfaction (Kohler et al. 2011) and controls/handles customers' emotional aspects to minimize dissatisfaction and complaints in the online environment. Other studies also mention that virtual agents play a significant role enhancing the customer experience (Luo, McGoldrick, Beatty, and Keeling 2006) and customer involvement and knowledge (Li, Sun, and Wilcox 2005), particularly in service sectors.

This study posits that interactivity plays an important role to the relationships for the improvement of negative sides of satisfaction. This study explores the effects of dissatisfaction on willingness to complain and actual complaining behavior, effects of willingness to complain and actual complaining behavior on repurchase intention, and repeat purchase intention on loyalty for cases of purchasing both non-sensory and sensory products and with effects of interactivity. This study posits that customers' expectation on interactivity with product categories affect i) dissatisfaction on willingness to complain or complaining behavior, ( $\mathrm{H} 4 \mathrm{~s} \sim 5 \mathrm{~s})$, ii) willingness to complain or complaining behavior on repurchase purchase intentions (H6s 7s), and iii) repurchase intention on loyalty (H8s). The following hypothesizes "c $\sim$ " for the impacts of interactivity in cases of purchasing non-sensory ("c") and sensory products (“d"),

H4c $\sim$ d: Effects of dissatisfaction on willingness to complain are higher with the high level of expectation on interactivity with cases of purchasing both non-sensory and sensory products.

H5c $\sim$ d: Effects of dissatisfaction on actual complaining behavior are higher with the high level of expectation on interactivity with cases of purchasing both non-sensory and sensory products.

H6c $\sim$ d: Effects of willingness to complain on repurchase intention are higher with the high level of expectation on interactivity with cases of purchasing both non-sensory and sensory products.

H7c $\sim$ d: Effects of complaining behavior on repurchase intention, in the case complaints are resolved are higher with the high level of expectation on interactivity with cases of purchasing both non-sensory and sensory products.

H8c $\sim$ d: Effects of repurchase intention on loyalty are higher with the high level of expectation on interactivity with cases of purchasing both non-sensory and sensory products.

Individualization including personalization or customization has addressed as a solution to improving firm-customer relationships in the virtualized environment. Even early start-up e-businesses, such as Amazon.com, apply individualization as an important factor to enhance satisfaction by applying systems, such as the recommender system which is also followed by other companies. Baye and Morgan (2009) address the development of customized applications, including one-click ordering, custom recommendations, and the development of an online community or culture loyalty. This paper considered both personalization (i.e., the degree to which the content is tailored by the system to individual tastes) and customization (i.e., the degree that the user deliberately choose options and/or create new content) as mediators (Sundar and Marathe 2010) for individualization to reduce customer dissatisfaction and complaining behavior and to increase repeat purchase behavior and loyalty. This study investigates how tools such as firm-oriented systems (e.g., collaborative filling system, recommender system) or user-initiated customizable system (Sundar and Marathe 2010; e.g., my virtual model by landsend.com, cyworld.com) maximize interactivity and individualization and reduce the dissatisfaction, willingness to complain and make complaints, repurchase, and loyalty. In particular, in the customization setting, design support can reduce anxiety and improve customer satisfaction and value consumers place on their own behavioral resources (Moreau, Bonney, and Herd 2011). Customers' attitudes toward individualized services are explained by behavioral decision theory that discussed 
"insight into their own preferences" (Valenzuela, Dhar, and Zettelmeyer 2009, Moreau, Bonney, and Herd 2011). The theory states that for many consumers, customizing products for oneself can result in frustration or anxiety (Valenzuela, Dhar, and Zettelmeyer 2009, Moreau, Bonney, and Herd 2011).

This study explores the effects of dissatisfaction to willingness to complain and actual complaining behavior, willingness to complain and actual complaining behavior to repurchase intention, and repeat purchase intention to loyalty for effects on individualization and with cases of purchasing both non-sensory and sensory products. This study posits that customers' expectation on individualization with product categories affect i) dissatisfaction on willingness to complain or complaining behavior, (H4s $\sim \mathrm{s}$ ) ii) willingness to complain or complaining behavior on repurchase purchase intentions (H6s 7s), iii) repurchase intention on loyalty (H8s). This study hypothesizes "e $\sim \mathrm{f}$ " for the impacts of individualization in cases of purchasing non-sensory ("e") and sensory products ("f $\mathrm{f}$ ").

H4e $\sim$ : Effects of dissatisfaction on willingness to complain are higher with the high level of expectation on individualization with cases of purchasing both non-sensory and sensory products.

H5e $\sim$ : Effects of dissatisfaction on actual complaining behavior are higher with the high level of expectation on individualization with cases of purchasing both non-sensory and sensory products.

H6e $\mathbf{f}$ : Effects of willingness to complain on repurchase purchase intention are higher with the high level of expectation on individualization with cases of purchasing both non-sensory and sensory products.

H7e $\sim$ f: Effects of complaining behavior on repurchase intention, in the case complaints are resolved, are higher with the high level of expectation on individualization with cases of purchasing both non-sensory and sensory products.

H8e $\sim$ f: Effects of repurchase intention on loyalty are higher with the high level of expectation on individualization with cases of purchasing both non-sensory and sensory products.

\section{METHODOLOGY}

This study, first, examines effects of justice dimensions on customer dissatisfaction and willingness to complain/complaining behavior by investigating differential effects by product category, non-sensory and sensory goods. Further, this study investigates links among dissatisfaction, complaining behavior/intention to complain, repeat purchase intention, and loyalty with the effects of advanced services, 2Is. A well-known research firm assisted online data collection by distributing the survey to panels that have online purchasing experiences with both product categories. This study applied stratified sampling in the data collection process of data based on the percentage of customers according to gender, age, education, income, field of work, and geographical location based on residency. A total of six hundred and eighteen respondents completed the survey, with a response rate of $45.8 \%$.

Multi-item scales were used to measure each of the constructs that serve as the basis for the questionnaire items. The questionnaire consists of two major parts to request opinions based on non-sensory and sensory products. This study applied a seven-point Likert scale with higher numbers representing higher levels of feelings, such as strongly agree (Cho 2011). It also included several open-ended questions. The items developed some scales taken from previous studies (Oliver, 1997; Oliver 1980; Cho 2011; Cho, Im, and Hiltz 2003, Blodgett, Hill, and Tax 1997; Blodgett, Granbois, and Walters 1993) and were modified to serve the objectives of this study. Three experts with experience in the area reviewed the survey items. After the review and a pilot study, the researchers selected approximately 70 items to represent the major constructs, such as three dimensions of justice, dissatisfaction, willingness to complain/actual complaining behavior, repeat purchase behavior, and loyalty with effects of advanced services and product category. The applied Cronbach's alpha provided the construct reliability for multi-item scales of each construct. This study found that Cronbach's alpha for three justice dimensions in the case of non-sensory product purchase shows 0.84 (distributive justice), 0.68 (procedural justice), 0.86 (interactional justice), as well as 0.70 for (dissatisfaction). Cronbach's alpha for three justice dimensions in the case of sensory product purchase showed 0.86 (distributive justice), 0.67 (procedural justice), 0.91 (interactional justice), and 0.81 for (dissatisfaction). The study also found Cronbach's alpha of above 0.80 for propensity to complain, 0.83 for complaining behavior, 0.88 for repeat purchase intention, and 0.93 for loyalty. Cronbach's alpha for the other constructs showed both 0.92 for interactivity and individualization in the case of non-sensory products as well as 0.94 for interactivity and 0.93 for individualization in the case of sensory products. This study examined the effects of advanced services for the effects of dissatisfaction to willingness to complain/complaining behavior, willingness to complain/complaining 
behavior to repeat purchase behavior and repeat purchase behavior to loyalty. This study consider major effects of advanced services from the stage of dissatisfaction by considering overall dissatisfaction.

\section{DATA ANALYSIS}

\subsection{Respondents Demographics}

Of the six hundred and eighteen respondents, $39.8 \%$ are female and $60.2 \%$ were male. About $19.0 \%$ were between the ages of 20-29 years old; $31.7 \%$ were between the ages of $30-39$ years old; $32.4 \%$ were in there 40 s; and $16.3 \%$ were 50 years old or older. Approximately $20.7 \%$ report that their highest educational level was a high school graduate, $15.8 \%$ had an associate's degree, and $49.6 \%$ had an undergraduate degree, and $14.0 \%$ had a graduate degree. About $10 \%$ of respondents stated their annual incomes was less than $\$ 20,000,32.5 \%$ between $\$ 30,000$ and $\$ 50,000,31.5 \%$ were between $\$ 50,000$ and $\$ 70,000$, and $23 \%$ were more than $\$ 70,000$. About $9.4 \%$ stated they were self-employed, $11.9 \%$ were housewives, $8.0 \%$ were blue color workers, $56.6 \%$ were white color workers, and $8.8 \%$ were students.

\subsection{Hypotheses Testing}

The study validates the factors of justice dimensions, dissatisfaction, willingness to complain, complaining behavior, repurchase intention, loyalty and advanced services. This study applied factor analyses to check the validity of constructs for justice dimension. Using principal components analyses as the extraction method and Varimax rotation methods with Kaiser Normalization, the most relevant data emerged. The results of factor analyses show that items represent major variables for non-sensory and sensory products and provide distinct reduced factors with Eigen values over 1.00. Table 1 shows factor analysis results for the justice dimension with the case of non-sensory products while Table 2 shows factor analysis results for the justice dimension with the case of sensory products.

Table 1: Component Matrix: The Case of Justice Dimension with Non-Sensory Products

\begin{tabular}{|c|c|c|c|c|}
\hline \multicolumn{2}{|r|}{ Items } & \multicolumn{3}{|c|}{ Components } \\
\hline Factors & Scale Items & 1 & 2 & 3 \\
\hline Distributive 4 & I think that the condition of delivered non-sensory products is in general acceptable. & .862 & & \\
\hline Distributive 3 & I think that overall, the delivered non-sensory products fit into my expectation. & .845 & & \\
\hline Distributive 5 & $\begin{array}{l}\text { I think that information about non-sensory products provided by online is } \\
\text { reasonable. }\end{array}$ & .842 & & \\
\hline Distributive 7 & Follow-up service after my purchase non-sensory products online is fair. & .796 & & \\
\hline Distributive 6 & $\begin{array}{l}\text { Amount of discount offered for non-sensory products online is reasonable compared } \\
\text { to the offline. }\end{array}$ & .730 & & \\
\hline Distributive 8 & $\begin{array}{l}\text { I don't think that there are lots of complaints along with service failure when I } \\
\text { purchase non-sensory products online. }\end{array}$ & .706 & & \\
\hline Distributive 1 & $\begin{array}{l}\text { I think that it is easy to refund or exchange non-sensory products that are purchased } \\
\text { online. }\end{array}$ & 634 & & \\
\hline Interactional 3 & $\begin{array}{l}\text { I wish that I could receive response about my questions via online sources such as } \\
\text { email as soon as possible. }\end{array}$ & & .855 & \\
\hline Interactional 4 & $\begin{array}{l}\text { I wish that I could receive response about my questions via online sources with } \\
\text { satisfactory response manner. }\end{array}$ & & .852 & \\
\hline Interactional 5 & $\begin{array}{l}\text { I think that I would be dissatisfied if my questions to the sales person are not } \\
\text { resolved by the first contact. }\end{array}$ & & .841 & \\
\hline Interactional 6 & $\begin{array}{l}\text { I would decide more easily if the sales person provides me with enough } \\
\text { explanation. }\end{array}$ & & .831 & \\
\hline Interactional 7 & $\begin{array}{l}\text { I often affected by the other person's responses that are mentioned based on } \\
\text { previous purchase. }\end{array}$ & & .715 & \\
\hline Procedural 3 & I often hesitate to buy non-sensory products due to the procedure. & & & .827 \\
\hline Procedural 4 & $\begin{array}{l}\text { I am often disappointed with delivery time when I order non-sensory products } \\
\text { online. }\end{array}$ & & & .802 \\
\hline Procedural 6 & I think that procedure to purchase non-sensory products online should be improved. & & & .738 \\
\hline
\end{tabular}


Table 2: Component Matrix: The Case of Justice Dimension with Sensory Products

\begin{tabular}{|c|c|c|c|c|}
\hline \multicolumn{2}{|r|}{ Items } & \multicolumn{3}{|c|}{ Components } \\
\hline Factors & Scale Items & 1 & 2 & 3 \\
\hline Distributive 4 & I think that the condition of delivered sensory products is in general acceptable. & .847 & & \\
\hline Distributive 5 & I think that information about sensory products provided by online is reasonable. & .841 & & \\
\hline Distributive 7 & Follow-up service after my purchase sensory products online is fair. & .817 & & \\
\hline Distributive 3 & I think that overall, the delivered sensory products fit into my expectation. & .809 & & \\
\hline Distributive 8 & $\begin{array}{l}\text { I don't think that there are lots of complaints along with service failure when I } \\
\text { purchase sensory products online. }\end{array}$ & .769 & & \\
\hline Distributive 1 & $\begin{array}{l}\text { I think that it is easy to refund or exchange sensory products that are purchased } \\
\text { online. }\end{array}$ & .732 & & \\
\hline Distributive 6 & $\begin{array}{l}\text { Amount of discount offered for sensory products online is reasonable compared to } \\
\text { the offline. }\end{array}$ & .718 & & \\
\hline Interactional 6 & $\begin{array}{l}\text { I would decide more easily if the sales person provides me with enough } \\
\text { explanation. }\end{array}$ & & .890 & \\
\hline Interactional 4 & $\begin{array}{l}\text { I wish that I could receive response about my questions via online sources with } \\
\text { satisfactory response manner. }\end{array}$ & & .883 & \\
\hline Interactional 3 & $\begin{array}{l}\text { I wish that I could receive response about my questions via online sources such as } \\
\text { email as soon as possible. }\end{array}$ & & .879 & \\
\hline Interactional 5 & $\begin{array}{l}\text { I think that I would be dissatisfied if my questions to the sales person are not } \\
\text { resolved by the first contact. }\end{array}$ & & .846 & \\
\hline Interactional 2 & It would be ideal if I could contact with sales person via real-time chatting service. & & .802 & \\
\hline Interactional 7 & $\begin{array}{l}\text { I often affected by the other person's responses that are mentioned based on } \\
\text { previous purchase. }\end{array}$ & & .714 & \\
\hline Interactional 1 & $\begin{array}{l}\text { I prefer to purchase sensory products online with more interactions with online } \\
\text { real-time salesperson. }\end{array}$ & & .713 & \\
\hline Procedural 4 & I am often disappointed with delivery time when I order sensory products online. & & & .805 \\
\hline Procedural 6 & I think that procedure to purchase sensory products online should be improved. & & & .801 \\
\hline Procedural 3 & I often hesitate to buy sensory products due to the procedure. & & & .800 \\
\hline
\end{tabular}

Further, this study applied analyses, such as regression analysis, the analysis of variance (ANOVA), and the analysis of covariance (ANCOVA). The Table 3 provides the results of regression analyses using factor scores for the effects of types of justice to the dissatisfaction. Overall, the results of the ANOVA in the case of impacts based on non-sensory and sensory products find the models significant at the .01 level with $F=160.388$ ( $r$-square $=.441)$ and $F=218.110$ ( $r$-square $=.517)$. The results of regression analyses demonstrate that effects of justice dimension on dissatisfaction are all accepted (H1a, 1b, 2a, 2b, and 3a, and 3b).

Table 3: Summary of the Effects of Justice Dimension to Dissatisfaction for both Cases of Non-Sensory and Sensory Products

\begin{tabular}{|l|c|c|}
\hline \multirow{2}{*}{ Variable (Independent -> Dependent) } & \multicolumn{2}{c|}{ Standardized Coefficient (t-value-Sig) } \\
\cline { 2 - 3 } & Non-Sensory Products (H “a”s) & Sensory Products \\
\hline Distributive Justice-> Dissatisfaction (H1a b) & $0.093(3.037 * * *)$ & $0.080(2.843 * * *)$ \\
\hline Procedural Justice -> Dissatisfaction $(\mathrm{H} 2 \mathrm{a} \sim \mathrm{b})$ & $0.192\left(6.239^{* * *)}\right.$ & $0.232\left(7.720^{* * *}\right)$ \\
\hline Interactional Justice -> Dissatisfaction $(\mathrm{H} 3 \mathrm{a} \sim \mathrm{b})$ & $0.595\left(19.353^{* * *}\right)$ & $0.605(20.147 * * *)$ \\
\hline
\end{tabular}

*** Significant at 0.01 level (2-tailed).

This study also applies regression analyses for the impacts of customers' dissatisfaction on the willingness to complain and actual complaining behavior for both non-sensory and sensory products. As shown in Table 4, this study demonstrates that effects of dissatisfaction on the willingness to complain $(\mathrm{H} 4 \mathrm{a} \sim \mathrm{b})$ and dissatisfaction on actual complaining behavior are significant $(\mathrm{H} 5 \mathrm{a} \sim \mathrm{b})$ for both cases of non-sensory and sensory products. The results of the analysis for the effects of dissatisfaction to the willingness to complain find the models significant at the 0.01 level with $F=11.956(r$-square $=.057)$ in the case of non-sensory product and $F=7.369$ ( $r$-square $=.036)$ in the case of sensory product. The results of the analysis for the effects of dissatisfaction to the actual complaining behavior prove that the models are significant at the 0.01 and 0.05 level with $F=17.747$ ( $r$-square $=.082$ ) in the case of non-sensory product and $F=3.973(r$-square $=.020)$ in the case of sensory product. 
Table 4: Summary of the Effects of Variables for both Cases of Non-Purchase and Purchase

\begin{tabular}{|l|c|c|}
\hline \multirow{2}{*}{ Variables (Independent -> Dependent) } & \multicolumn{2}{c|}{ Standardized Coefficient $(\boldsymbol{t}$-value-Sig) } \\
\cline { 2 - 3 } & Non-Sensory Products (H “a”s) & Sensory Products \\
\hline Dissatisfaction -> Willingness to Complain (H 4a b) & $0.287(4.213 * * *)$ & $0.189(2.715 * * *)$ \\
\hline Dissatisfaction -> Complaining Behavior (H5a b) & $0.239\left(3.458^{* * *)}\right.$ & $0.140(1.993 * *)$ \\
\hline Willingness to Complain -> Repurchase Intention (H6a b) & $0.135\left(3.659^{* * *}\right)$ & $0.207\left(5.230^{* * *}\right)$ \\
\hline Complaining Behavior -> Repurchase Intention (H7a b) & $0.230(3.325 * * *)$ & $0.223(3.214 * * *)$ \\
\hline Repurchase Intention -> Loyalty (H8a b) & $0.478(13.457 * * *)$ & $0.456(12.698 * * *)$ \\
\hline
\end{tabular}

*** Significant at 0.01 level (2-tailed); ** Significant at 0.05 level (2-tailed)

This study also applied regression analyses for the impacts of the willingness to complain and actual complaining behavior to repurchase intention for both non-sensory and sensory products (H6a b \& H7a b). Overall, the results of the analysis for the effects of willingness to complain to repurchase intention found that the models are significant at the 0.01 level with $F=13.391(r$-square $=.063)$ in the case of non-sensory product and $F=27.354$ $(r$-square $=.083)$ in the case of sensory product. Overall, the results of the analysis for the effects of actual complaining behavior to repurchase intention behavior when complaints are well resolved, determined that the models are significant at the 0.01 level with $F=11.057$ ( $r$-square $=.053)$ in the case of non-sensory product and $F=$ 10.331 ( $r$-square $=.050$ ) in the case of sensory product. Therefore, the study accepted H6a $\sim \mathrm{b}$ and H7a b (see Table 5). The Table 4 also demonstrates the effects of repurchase intention to loyalty. The results of regression analysis for the effects of repurchase intention to loyalty indicate that the models are significant at the 0.01 level with $F=$ 181.089 ( $r$-square $=.228)$ in the case of non-sensory product and $F=161.248(r$-square $=.208)$ in the case of sensory product. Therefore, the study accepted H8a b.

This study applied ANCOVA to examine effects of i) the dissatisfaction on willingness to complain and actual complaining behavior, ii) willingness to complain and actual complaining behavior on repurchase intention, and iii) repurchase intention on loyalty based on expectation of the 2Is, interactivity and individualization with cases of purchasing non-sensory and sensory products. Table 5 provides the results related to H4c $\sim \mathrm{f} \sim \mathrm{H} 8 \mathrm{c} \sim \mathrm{f}$. As shown in Table 5, effects of the dissatisfaction on willingness to complain for the case of interactivity are significant at the 0.01 level $(F$-value $=10.786$ and 11.087) for both cases of non-sensory and sensory products $(\mathrm{H} 4 \mathrm{c} \sim \mathrm{d})$. Effects of the dissatisfaction on willingness to complain for the case of individualization are significant at the 0.01 ( $F$-value $=$ 11.067 and 15.496) for both cases of non-sensory and sensory products (H4e f). Effects of the dissatisfaction on complaining behavior for the case of interactivity are significant at the 0.01 level $(F$-value $=12.751$ : H5c $)$ for the case of non-sensory and significant at the 0.05 level for the case of sensory products ( $F$-value $=6.792$ : H5d). Effects of the dissatisfaction on complaining behavior for the case of individualization are significant at the 0.01 level $(F$-value $=12.452: \mathrm{H} 5 \mathrm{e})$ for the case of non-sensory and 0.05 level for the case of sensory products $(F$-value $=5.691$ : H5f). Therefore, the findings accept hypotheses $\mathrm{H} 4 \mathrm{c} \sim \mathrm{d}, \mathrm{H} 4 \mathrm{e} \sim \mathrm{f}, \mathrm{H} 5 \mathrm{c} \sim \mathrm{d}$, and H5e f. The results of ANCOVA show that higher level of interactivity and individualization affects the impact of dissatisfaction to willingness to complain and complaining behavior for both cases of purchasing non-sensory and sensory products.

Table 5: Summary of the Effect of the Variables based on Expectation on Interactivity and Individualization with Cases of Purchasing Non-Sensory and Sensory Products

\begin{tabular}{|c|c|c|c|c|}
\hline \multirow[b]{2}{*}{$\begin{array}{c}\text { Effects of Variables Based on } \\
\text { Interactivity and } \\
\text { Individualization with Product } \\
\text { Categories }\end{array}$} & \multicolumn{4}{|c|}{$F$-value (Sig) } \\
\hline & $\begin{array}{c}\text { Expectation on } \\
\text { Interactivity for } \\
\text { Non-Sensory } \\
\text { Products (H "c"s) }\end{array}$ & $\begin{array}{c}\text { Expectation on } \\
\text { Interactivity for } \\
\text { Sensory Products } \\
\text { (H “d”s) }\end{array}$ & $\begin{array}{c}\text { Expectation on } \\
\text { Individualization } \\
\text { for Non-Sensory } \\
\text { Products (H "e"s) }\end{array}$ & $\begin{array}{c}\text { Expectation on } \\
\text { Individualization } \\
\text { for Sensory } \\
\text { Products(H "f"s) }\end{array}$ \\
\hline $\begin{array}{l}\text { Dissatisfaction on Willingness to } \\
\text { Complain }(\mathrm{H} 4 \mathrm{c} \sim \mathrm{f})\end{array}$ & $10.786(0.001 * *)$ & $11.087(0.001 * * *)$ & $11.067(0.001 * * *)$ & $15.496(0.000 * * *)$ \\
\hline $\begin{array}{l}\text { Dissatisfaction on Complaining } \\
\text { Behavior }(\mathrm{H} 5 \mathrm{c} \sim \mathrm{f})\end{array}$ & $12.751(0.000 * * *)$ & $6.792\left(0.010^{* *}\right)$ & $12.452(0.001 * * *)$ & $5.691(0.018 * *)$ \\
\hline $\begin{array}{l}\text { Willingness to Complain on } \\
\text { Repurchase Intention (H6c f) }\end{array}$ & $5.313\left(0.006^{* * *}\right)$ & $8.008(0.000 * * *)$ & $4.832(0.009 * * *)$ & $9.340(0.000 * * *)$ \\
\hline $\begin{array}{l}\text { Complaining Behavior on } \\
\text { Repurchase Intention }(\mathrm{H} 7 \mathrm{c} \sim \mathrm{f})\end{array}$ & $5.321(0.006 * * *)$ & $4.344(0.014 * *)$ & $2.860(0.060 *)$ & $4.965(0.008 * * *)$ \\
\hline $\begin{array}{l}\text { Repurchase Intention on Loyalty } \\
\text { (H8c f) }\end{array}$ & $9.393(0.000 * * *)$ & $5.248\left(0.006^{* * *}\right)$ & $9.724(0.000 * * *)$ & $4.103\left(0.018^{* *}\right)$ \\
\hline
\end{tabular}


Effects of the willingness to complain on repurchase intention for the case of interactivity are significant at the 0.01 level $(F$-value $=5.313$ and 8.008$)$ for cases of non-sensory and sensory products $(\mathrm{H} 6 \mathrm{c} \sim \mathrm{d})$. Effects of the willingness to complain on repurchase intention for the case of individualization are significant at the 0.01 level $(F$-value $=4.832$ and 9.340) for cases of non-sensory and sensory products (H6e f). The results of actual complaining behavior on repurchase intention for the case of interactivity are significant at the 0.01 level $(F$-value $=$ $5.321)$ and the 0.05 level $(F$-value $=4.344)$ for cases of non-sensory and sensory products $(\mathrm{H} 7 \mathrm{c} \sim \mathrm{d})$. Effects of the actual complaining behavior on repurchase purchase intention for the case of individualization are significant at the 0.10 level $(F$-value $=2.860)$ and the 0.01 level $(F$-value $=4.965)$ for cases of non-sensory and sensory product (H7e f). Therefore, the findings accept hypotheses H6c d, H6e $\mathrm{f}, \mathrm{H} 7 \mathrm{c} \sim \mathrm{d}$, and H7e f. The results of ANCOVA show that higher level of interactivity and individualization affects the impact of willingness to complain and actual complaining behavior (in the case that complaints are resolved) to repurchase intention, and repurchase intention to loyalty. The results are applied for both cases of purchasing non-sensory and sensory products.

This study also applied ANCOVA to examine the effect of repurchase intention on loyalty based on the expectation of the 2Is, interactivity and individualization with cases of purchasing non-sensory and sensory products (H8c $\sim$ d \& H8e f). As shown in Table 5, the results of repurchase intention on loyalty for the case of interactivity are significant at the 0.01 level $(F$-value $=9.393$ and 5.248) for cases of non-sensory and sensory product (H8c d). Effects of the repurchase intention on loyalty for the case of individualization are significant at the 0.01 level $(F$-value $=9.724)$ and the 0.05 level $(F$-value $=4.103)$ for cases of non-sensory and sensory product $(\mathrm{H} 8 \mathrm{e} \sim \mathrm{f})$. Results also show that both interactivity and individualization affect the impacts of repurchase intention and loyalty for both cases of non-sensory and sensory products.

\section{DISCUSSION AND CONCLUSION}

The purpose of this paper is to explore the relationship between justice dimension, dissatisfaction, willingness to complain, actual complaining behavior, repeat purchase intention, and loyalty in the virtualized environment. This study addresses the solution of Customer Relationship Management (CRM) with the development of strategic relationships among factors, such as dissatisfaction, willingness to complain, complaining behavior, repurchase intention, and loyalty with roles of advanced services and product category. By considering the impact of virtualization and telepresence, i.e., customers cannot try, see, touch the product via online due to lack of physical presence (Cho 2011), this study examined how the effects of those relationships differ based on applied effects of advanced services, interactivity and individualization (Mohammed, Fisher, Jaworski, and Cahill 2002), which addressed strategies to minimize customer dissatisfaction and complaints in the computer-mediated shopping environment (Hoffman and Novak, 1996). This study also examined effects based on the product categories, namely non-sensory and sensory products. Proposed relationships were considered as the pivotal role in relational exchanges and creating customer value and loyalty (Sirdeshmukh, Singh, and Sabol 2002; Satos, Brodie, and Whittome 2010). This study first finds significant relationships such as i) how justice dimensions from online shopping affect dissatisfaction; ii) how the level of dissatisfaction affects the willingness to complain and actual complaining behavior; iii) how the level of willingness to complain and complaining behavior affects repurchase intention; and iv) how repurchase intention affects loyalty. Second, effects of proposed relationships examined as significant with advanced services, interactivity and individualization, and also with product categories.

The results show that effects of dissatisfaction to willingness to complain and complaining behavior are significant for both cases of non-sensory and sensory products. Compared to the previous studies in the case of offline environment, this study finds that dissatisfaction lead to both willingness to complain and complaining behavior. Previously, studies discuss that dissatisfied customers are hardly express their complaints due to many issues such as unsatisfactory response that might not meet customers' expectation and consideration of the following activity which is troublesome. In addition, the study finds that impacts of dissatisfaction to willingness to complain and complaining behavior are slightly higher with non-sensory products than sensory products. Effects of dissatisfaction on willingness to complain and dissatisfaction on complaining behavior show significant with the cases of higher expectation on interactivity and individualization. The results are significant for both cases of purchasing non-sensory and sensory products. Results give us implication that higher expectation on interactivity and individualization help improve process between dissatisfaction to willingness to complain and complaining behavior. The results give us implication that customers' expectation on interactivity and individualization is 
considered as meaningful factor to reduce the level of effects of dissatisfaction to the willingness to complain and complaining behavior when they make purchase decisions online. This study finds that willingness to complain and complaining behavior lead to the repeat purchase intention with the condition that complaints are well resolved. This study also finds that willingness to complain on repurchase intention with the expectation on both interactivity and individualization is significant for both cases of non-sensory and sensory products. Therefore, the result also provides that effects of willingness to complain and complaining behavior on repurchase intention in the case complaints are revolved with the higher expectation on interactivity and individualization are significant for both cases of non-sensory and sensory product. This study also finds that effects of repurchase intention on loyalty with the higher expectation on interactivity and individualization are significant.

Theoretically, this study contributes to the development of the relationships among dissatisfaction, complaining behavior, and loyalty in the virtualized environment. Various researchers examine the issues of satisfaction in the virtualized environment, but not many studies investigate issues of dissatisfaction. The study also explores the relationships among willingness to complain/actual complaining behavior and repeat purchase intention, which has paid less attention in the virtual environment. In particular, proposed relationships are measured with roles of advanced services, interactivity and individualization and product categories. This study explored how advanced services, 2Is needed for the development of current e-businesses, play a significant role in improving relationships between willingness to complain/complaining behavior and repeat purchase intention. Prior studies (Levesque and McDougall 1996) examined that maintaining stable strategies while developing customer loyalty and solving problems associated with customer complaint data in the offline environment are crucial to success. The Web, known as a sticky place, provides more opportunities to increase loyalty (Reichheld and Schefter 2000) and minimizes problems by applying technology-enabled strategies. By applying both theoretical insights, this study proves that relationships between complaining behavior and loyalty on the Web are fundamental for the strategic issues of Customer Relationship Management (CRM).

Managerially, this study provides implications and suggestions to e-Commerce Customer Relationship Management (eCCRM) by proposing how important the remedies are to customer dissatisfaction, which become a means of earning customer loyalty and attracting new customers (Cho et al., 2001). By considering factors such as advanced services and product category, this study provides directions for e-businesses to develop more advanced customer service to meet savvy customers' dissatisfaction, handle customer complaints, and increase long-term loyalty. This study posits that a need for a specialized system is the solution to minimize dissatisfaction and to maintain loyalty as current customers are more likely characterized as "digital natives" (Prensky 2005) with the need for stronger relationships with frequent information exchange, preference formation, and purchase decisions (Kohler et al. 2011). Advanced services for individualization, another of the 2Is, also known as customization, play an important role in grasping the attention of and increasing the shoppers' positive attitudes and satisfaction. In particular, results of the study reveal how to handle interactivity and individualization is significant key to manage relationships between dissatisfaction and willingness to complain and complaining behavior. The study also addresses that the importance of successful management in dealing with customer dissatisfaction for stability and profitable growth, as well as determining how comprehensive a complaint response strategy must be to satisfy online customers and gain their long-term loyalty (Cho 201; Cho et al, 2001; Levesque and McDougall, 1996) are vital to improve CRM in the virtualized environment.

The study has implications. First, this study explored relationships on the negative sides of satisfaction that also lead to loyalty in the virtualized environment. Second, this study addresses the need for better applications such as the effects of advanced services, to explore the relationships among dissatisfaction and loyalty online. Third, this study also investigated how the justice dimension, applied with the concept of equity, makes links with customer dissatisfaction in the virtualized environment. Although this study applies multivariate statistics, further studies might consider the measurement of a cause and effect relationship. Finally, further research might consider applications to other environments, such as cross-cultures/countries, for generalization.

\section{ACKNOWLEDGEMENT}

The author is grateful for the financial support from the KDI School of Public Policy and Management. 


\section{AUTHOR INFORMATION}

Dr. Yoon C. Cho is a Professor at the KDI School of Public Policy and Management, global school, located in Seoul. She published research papers in the various academic journals such as Journal of Business Research (JBR), Advances in Consumer Research (ACR), Journal of Business \& Economics Research (JBER), etc. E-mail: ycho@kdischool.ac.kr

\section{REFERENCES}

1. Bakos, J. Yannis (1997), "Reducing Buyer Search Costs: Implications for Electronic Marketplaces," Management Science, 43(12), 1676-1692.

2. Baye, Michael R. and John Morgan (2009), "Brand and Price Advertising in Online Markets," Management Science, 55(7), 1139-1151.

3. Bearden, William O. and Jesse, E. Teel (1983), "Selected Determinants of Consumer Satisfaction and Complaint Reports," Journal of Marketing Research, 20(February), 21-28.

4. Bearden, William. O., M. Crockett, and S. Graham, (1979), "Consumers' Propensity-to-Complain and Dissatisfaction with Automobile Repairs," Refining Concepts and Measures of Consumer Satisfaction and Complaining Behavior, Indiana University, Bloomington, Indiana, edited by H. Keith, Hunt and Ralph L. Day, (October), 35-43.

5. Berry, Leonard L. and A. Parasuraman (1991), Marketing Services: Competing through Quality, New York: Free Press.

6. Berger, Joseph, Thomas L. Conner, and Hamit M. Fisek (1974), Expectation States Theory: A Theoretical Research Program, Winthrop Publishers, Cambridge, MA.

7. Bies, Robert J. and Debra L. Shapiro (1987), "International Fairness Judgments: The Influence of Causal Accounts," Social Justice Research, 1, 199-218.

8. Bitner, M. J., B. M. Booms, and M. S. Tetreault (1990), "The Service Encounter: Diagnosing Favorable and Unfavorable Incidents," Journal of Marketing, 54(January), 71-85.

9. Blodgett, Jeffrey G., Donna J. Hill, and Stephen S. Tax (1997), "The Effects of Distributive, Procedural, and Interactional Justice on Postcomplaint Behavior," Journal of Retailing, 73(2), 185-210.

10. Blodgett Jeffrey G., Donald. H. Granbois, and Rockney. G. Walters (1993), "The Effects of Perceived Justice on Negative Word-of-Mouth and Repatronage Intentions," Journal of Retailing, 69(Winter), 399-428.

11. Brett, Jeanne M. (1986), "Commentary on Procedural Justice Papers," in Research on Negotiation in Organizations, 1, Roy Lewicki. Max Bazerman, and Blair Sheppard, eds. Greenwich, CT: JAI Press, 81-90.

12. Cardozo, Richard N. (1964), "Customer Satisfaction: Laboratory Study and Marketing Action," Journal of Marketing Research, 2, 244-9.

13. Coates, G. (1992), "Program from Invisible Site - a Virtual Sho, a Multiple Performance Work," presented by George Coates Performance Works, (March), San Francisco, CA.

14. Cohen, Joel B. and Marvin, E. Goldberg (1970), "The Dissonance Model in Post-Decision Product Evaluation," Journal of Marketing Research, 7(3), 315-321.

15. Chen, Lei-Da and Justin Tan (2004), "Technology Adaption in E-Commerce: Key Determinants of Virtual Stores Acceptance," European Management Journal, 22(1), 74-86.

16. Cho, Y. (2011), "Analysis of Customer Dissatisfaction toward Perishable Grocery Goods," Journal of Business Research, Vol. 64, pp.1245-1250.

17. Cho, Y. (2010), "Assessing Customer Satisfaction and Acceptance on Perishable Goods In the "Telepresent" Environments," Journal of Business \& Economics Research, September, 8(9), 23-35.

18. Cho, Y. and J. Agrusa (2007), "How the Media is a Significant Promotional Tool to Deliver Marketing Messages to Audiences?" International Business \& Economics Research Journal (IBER), 6(10), 61 - 74.

19. Cho, Y., I. Im, S. Hiltz (2003), “The Impact of E-Services Failures and Customer Complaints on Electronic Commerce Customer Relationship Management,” The Journal of Consumer Satisfaction, Dissatisfaction, and Complaining Behavior, (December), 106-131.

20. Cho, Y., I. Im, J. Fjermestad \& S. Hiltz (2003), “The Impact of Product Category on Customer Dissatisfaction in Cyberspace," A paper has been accepted in a Special Section on Electronic Customer Relationship Management in The Business Process Management Journal, (Winter). 
21. Cho, Y., I. Im, S. Hiltz \& J. Fjermestad (2001), The Effects of Post-Purchase Evaluation Factors on Online vs. Offline Customer Complaining Behavior: Implications for Customer Loyalty, Advances in Consumer Research (ACR), 29, 318-326.

22. Chu, Wujin, Eitan Gerstner, and James D. Hess (1998), "Managing Dissatisfaction: How to Decrease Customer Opportunism by Partial Refunds," Journal of Service Research, 1(2), 140-155.

23. Clarkson, Diane (2010), "How to Create a Social Customer Service Strategy," Forrester Research, June.

24. Clemmer, E. C. and B. Schneider (1996), Fair Service, in: Swartz T.A., Bowen, D.E., Brown, S.W., editors. Advances in Services Marketing and Management: Research and Practice, 5, Greenwich, CT:1 JAI Press, 109-126.

25. Day, Ralph and Laird, E. Landon (1977), "Toward a Theory of Consumer Complaining Behavior," in Consumer and Industrial Buying Behavior, A. G. Woodside, J.N. Sheth, and P.D. Bennett, eds. New York: North-Holland, 425-437.

26. Deutsch, Morten (1985), Distributive Justice, New Haven, CT: Yale University Press.

27. Dwyer, F. R., P. H. Schurr, S. Oh (1987), "Developing Buyer-Seller Relationships," Journal of Marketing, 51(5), 11-27.

28. Engel, James F. and Roger D. Blackwell (1982), Consumer Behavior, $4^{\text {th }}$ ed., New York, Holt, Rinehart and Winston.

29. Festinger, Leon (1957), A Theory of Cognitive Dissonance, Stanford, California: Stanford University Press.

30. Figueiredo, J. M. de (2000). Finding Sustainable Profitability in Electronic Commerce. Sloan Management Review, (Summer).

31. Fisk. Raymond P. and Kenneth A. Coney (1982), "Postchoice Evaluation: An Equity Theory Analysis of Consumer Satisfaction/Dissatisfaction with Service Choices," in Conceptual and Empirical Contributions to Consumer Satisfaction and Complaining Behavior, Keith Hunt and Ralph L. Day, eds., Bloomington: Indiana University, 9-16.

32. Folger, Robert (1987), "Distributive and Procedural Justice in the Workplace," Social Justice Research, 1, 143-160.

33. Folkes, Valerie S. (1984), “Consumer Reactions to Product Failures: An Attributional Approach,” Journal of Consumer Research, 10(March), 398-409.

34. Gehrt, K. C. and R. Yan (2004). Situational, Consumer, and Retailer Factors affecting Internet, Catalog, and Store Shopping. International Journal of Retail \& Distribution Management, 32(1), 5-18.

35. Gehrt, K.C., T.N. Ingram, and V. Howe (1991). Non-store versus Store Retailing: A Situationally Based Market Structure Assessment. Journal of Direct Marketing, 5(2), 44-53.

36. Greenberg, Jerald (1990), "Looking Fair Versus Being Fair: Managing Impressions of Organizational Justice," Research in Organizational Behavior, 12, 111-157.

37. Grewal, D., G., R. Iyer, and Michael Levy (2004). Internet Retailing: Enablers, Limiters and Market Consequences. Journal of Business Research, 57, 703-713.

38. Goodwin, Cathy and Ivan Ross (1989), "Salient Dimensions of Perceived Fairness in Resolution of Service Complaints," Journal of Consumer Satisfaction/Dissatisfaction and Complaining Behavior, 2, 87-92.

39. Goodwin, Cathy and Ross, Ivan (1992), "Consumer Responses to Service Failures: Influence of Procedural and Interactional Fairness Perceptions,” Journal of Business Research, 25, pp. 149-163.

40. Goodwin, C., \& Ross, I. (1989). Salient dimensions of perceived fairness in resolution of service complaints. Journal of Consumer Satisfaction, Dissatisfaction and Complaining Behavior, 2, 87-92.

41. Gustafsson, Anders (2009), “Customer Satisfaction with Service Recovery," Journal of Business Research, $62,1220-1222$.

42. Hansen, T. (2005). Consumer Adoption of Online Grocery Buying: A Discriminant Analysis. International Journal of Retail \& Distribution Management, 33(2), 101-121.

43. Hirschman, A. O. (1970). Exit, Voice, and Loyalty: Responses to Decline in Firms. Organizations and States. Cambridge, MA: Harvard University Press.

44. Hocutt, Mary Ann, Goutam Chakaborty, and John C. Mowen (1997), "The Impact of Perceived Justice on Customer Satisfaction and Intention to Complain in a Service Recovery," Advances in Consumer Research, Vol. 24, pp. 457-463.

45. Hoffman Donna. L. and Novak, Thomas P. (1996), "Marketing in Hypermedia Computer-Mediated Environments: Conceptual Foundations," Journal of Marketing, 60, pp.50-68. 
46. Hormas, Geroge Caspar (1961), Social Behavior: Its Elementary Forms, Harcourt, Brace \& World, New York.

47. Howard, John A. and Jagdish N. Sheth (1969), The Theory of Buyer Behavior, New York, John Wiley and Sons.

48. Huefner, Jonathan C. and H. Keith Hunt (2000), "Consumer Retaliation as a Response to Dissatisfaction," Journal of Consumer Satisfaction, Dissatisfaction, and Complaining Behavior, 13, 61-82.

49. Hui, Michael K. and Kevin Au (2001), "Justice Perceptions of Complaint-Handling: A Cross-Cultural Comparison between PRC and Canadian Customers," Journal of Business Research, 52, 151-173.

50. Iyer, Ganesh and Amit Pazgal (2003), "Internet Shopping Agents: Virtual Co-Location and Competition," Marketing Science, (Winter), 85-106.

51. Jung, Kwon, Yoon C. Cho, and Sun Lee (2011), “Analysis of Online Shopping Comparison Sites: Effects of Price Comparison Site Information, Online Shoppers' Price Consciousness and Product Type on Price and Value Perceptions," AMA Summer Marketing Educators' Conference, San Francisco, CA, forthcoming.

52. Kohler, Clemens, F., Andrew, J. Rohm, Ko de Ruyter, and Martin Wetzels (2011), "Return on Interactivity: The Impact of Online Agents on Newcomer Adjustment," Journal of Marketing, 75(March), 93-108.

53. Lages,Carmen, Luis Filipe Lages, and Paulo Rita (2004), "The Relationship between E-Marketing Strategy and Performance: A Conceptual Framework in a Web Context," Working paper.

54. Li, Shibo, Baohong Sun, and Ronald T. Wilcox (2005), "Cross-Selling Sequentially Ordered Products: An Application to Consumer Banking Services," Journal of Marketing Research, 42(May), 233-239.

55. Levesque, Terrence J. and Gordon H. G. McDougall (1996), “Customer Dissatisfaction: The Relationship Between Types of Problems and Customer Response," Canadian Journal of Administrative Sciences, 13(3), 264-276.

56. Lind, E. A., \& Tyler, T. R. (1988), The social Psychology of Procedural Justice. New York: Plenum.

57. Luo, J.T., Peter McGoldrick, Susan Beatty, and Kathleen A. Keeling (2006), "On-Screen Characters: Their Design and Influence on Consumer Trust," Journal of Service Marketing, 20(2), 112-124.

58. McMillan, Sally J. and Hwang, Jang-Sun (2002), "Measures of Perceived Interactivity: An Exploration of the Role of Direction of Communication, User Control, and Time in Shaping Perceptions of Interactivity," Journal of Advertising, 31(3), 29-42.

59. Maxham, James G. III and Richard G. Netemeyer (2002), "Modeling Customer Perceptions of Complaint Handling over Time: the Effects of Perceived Justice on Satisfaction and Intent," Journal of Retailing, 78, 239-252.

60. Massey, Brian L. and Levy, Mark, R. (1999), “Interactivity, Online Journalism, and English-Language Web Newspapers in Asia," Journalism \& Mass Communication Quarterly, 76(1), 138-151.

61. Mohammed, R.A., R.J. Fisher, B.J. Jaworski, and A.M. Cahill (2002) Internet Marketing: Building Advantage in a Networked Economy, McGraw-Hill.

62. Moreau, Page, C., Bonney, Leff, and Herd, Kelly B. (2011), "It's the Thought (and the Effort) That Counts: How Customizing for Others Differs from Customizing for Oneself," Journal of Marketing, 75, September, 120-133.

63. Oliver, R. L. (1980), A Cognitive Model of the Antecedents and Consequences of Satisfaction Decisions. Journal of Marketing Research, 17(November), 460-469.

64. Oliver, R. L. (1997), Satisfaction: A Behavioral Perspective on the Consumer, Irwin McGraw-Hill.

65. Palmer, J. W. (1997), "Electronic Commerce in Retailing: Differences across Retail Format," The information Society, 13, 75-91.

66. Parasuraman, A., Valarie Zeithaml, and Leonard Berry (1988), "Servqual: A Multiple-Item Scale for Measuring Consumer Perceptions of Service Quality,” Journal of Retailing, 64(1), 12-40.

67. Pan, Xikng, Brian T. Ratchford, and Shankar Venkatesh (2004), "Price Dispersion on the Internet: A Review and Directions for Future Research" Journal of Interactive Marketing, 18(4), 116-135.

68. Peppard, J. \& Rylander, A. (2005) "Products and services in cyberspace", International Journal of Information Management, 25, 335-345.

69. Ping, Robert A. Jr. (1993), "The Effects of Satisfaction and Structural Constraints on Retailer Existing, Voice, Loyalty, Opportunism, and Neglect," Journal of Retaining, 69(3), 320-352.

70. Pitt, L, P. Berthon, R. Watson, and M. Ewing (2001), "Pricing Strategy and the Net," Business Horizons, (March/April), 45-54. 
71. Prensky, Marc (2005), "Listen to the Natives," Educational Leadership, 63(4), 8-13.

72. Rafaeli, Sheizaf (1988), "Interactivity: From New Media to Communication," in Advancing Communication Science: Merging Mass and Interpersonal Processes, R. P. Hawkins, J.M. Wiemann and S. Pingree, eds. Newbury Park, CA: Sage Publications, 110-134.

73. Reichheld, Frederick F. and Phil Schefter (2000), "E-Loyalty: Your Secret Weapon on the Web," Harvard Business Review, (July-August).

74. Reichheld, Frederick, F. (1993), “Loyalty-Based Management," Harvard Business Review, (March-April), 64-73.

75. Rhee, Hyeun-Suk, Frederick, J. Riggins, and Cheongtasg Kim (2009), "The Impact of Product Type and Perceived Characteristics of the Web on Multifaceted Online Shopping Behavior," Journal of Organizational Computing and Electronic Commerce, 19, 1-29.

76. Río-Lanza, A. B., R. Vazquez-Casielles, A.M. Diaz-Martin, "Satisfaction with Service Recovery: Perceived Justice and Emotional Responses," Journal of Business Research, Forthcoming.

77. Satos, Laszlo, Brodie,Roderick, J., and Whittome, James (2010), "Impact of Service Failure: The Prospective Layer of Customer Relationships," Journal of Service Research, 13(2), pp. 216-229.

78. Schumann, Jan H., Keller, Nancy, V., Wangenheim, Florian V., and Holzmuller, Hartmut H. (2007), "Technology Mediation in Service Delivery: A New Typology and An Agenda for Managers and Academics," American Marketing Association, Winter, 44-45.

79. Shim, S., Eastlick, M.A., S.L. Lotz, and P. Warrington (2001), “An Online Repurchase Intentions Model: the Role of Intention to Search,” Journal of Retailing, 77, 397-416.

80. Sirdeshmukh, Deepak, Singh, Jagdip, and Sabol, Barry (2002), "Consumer Trust, Value, and Loyalty in Relationship Exchanges," Journal of Marketing, 66(1), pp. 15-37.

81. Solomon, Michael, R. (2009). Consumer Behavior: Buying, Having, and Being. $8^{\text {th }}$ edition, Pearson Prentice Hall.

82. Solomon, Michael R., Carol Surprenant, John A. Czepiel, and Evelyn G. Gutman (1985), "A Role Theory Perspective on Dyadic Interactions: The Service Encounter," Journal of Marketing, 49(Winter), 99-111.

83. Song, Ji Hee and George M. Zinkhan (2008), "Determinants of Perceived Web Site Interactivity," Journal of Marketing, 72(March), 99-113.

84. Steuer, Jonathan (1992), "Defining Virtual Reality: Dimensions Determining Telepresence," Journal of Communication, (Autumn), 73-93.

85. Stevenson, Julie, Bruner II. Gordon, and Kumar Anand (2000), "Webpage Background Viewer Attitudes," Journal of Advertising Research, 40(January), 29-34.

86. Sundar, S. Shyam and Marathe, Sampada S. (2010), "Personalization versus Customization: The Importance of Agency, Privacy, and Power Usage," Human Communication Research, 36, 298-322.

87. Tax, S. S., S. W. Brown, and M. Chandrashekaran (1998), "Customer Evaluations of Service Complaint Experiences: Implications for Relationship Marketing,” Journal of Marketing, 62, 60-76.

88. Thongpapanl, Nagongsak and Ashraf, Rehman Abdul (2011), "Enhancing Online Performance Through Website Content and Personalization," Journal of Computer Information Systems, Fall, 3-13.

89. Thorbjornsen, Helge and Magne Supphellen (2004), "The Impact of Brand Loyalty on Website Usage," Brand Management, 11(3), 199-208.

90. Verhoef, P. C. and F. Langerak (2001), "Possible Determinants of Consumers' Adoption of Electronic Grocery Shopping in the Netherlands," Journal of Retailing and Consumer Services, 8, 275-85.

91. Wendy, Macias (2003), “A Beginning Look at the Effects of Interactivity, Product Involvement and Web Experience on Comprehension: Brand Web Sites as Interactive Advertising," Journal of Current Issues and Research in Advertising, 25(2), Fall, 31-44.

92. Wu, Guohua (1999), "Perceived Interactivity and Attitude Toward Websites," in Proceedings of the American Academy of Advertising, M.S. Roberts, ed. Gainseville: University of Florida, 254-262. 